胸腔鏡下肺葉切除術を施行した食道癌術後発生原発性肺癌の 2 例

\author{
土肥良一郎, 町野 隆介, 森野 茂行 \\ 辻博治, 田川努
}

\begin{abstract}
要 旨
食道癌術後の原発性肺癌手術は困難であるとされ，原因は同側開胸後の高度癒着にある．今回，胸腔鏡下食道切除術後の 右上葉肺癌 2 例を胸腔鏡下に切除し, 手術要点の知見を得たので報告する. 症例 1 は 75 歳男性. 胸部食道癌に対し胸腔鏡下 食道切除, 2 領域リンパ節郭清, 胸骨後経路胃管再建を行い, 9 力月後に右上葉肺癌に対し胸腔鏡補助下肺葉切除を行った. 症例 2 は 60 歳女性. 胸部食道癌に対し胸腔鏡下食道切除, 2 領域リンパ節郭清, 後縦隔経路胃管再建を行い, 16 力後に右 上葉肺癌に対し胸腔鏡下肺葉切除を行った．胸腔鏡下食道切除術後は胸壁ポート孔と肺との間に癒着を認めなかった．再建 経路によって肺と縦隔との間の癒着の程度と剥離の要点が異なった. 右主気管支と奇静脈切離端付近に最も高度な癒着を認 めたが, \#4, \#10 リンパ節郭清に問題はなかった. 食道切除時に郭清されていたため\#2, \#7 リンパ節郭清は必要なかった.
\end{abstract}

索引用語 : 食道癌, 胸腔鏡下食道切除, 肺癌, 胸腔鏡下肺葉切除

esophageal cancer, VATS-E, lung cancer, VATS lobectomy

はじめに

食道癌術後の原発性肺癌手術は困難であるとされる。 その原因は同側開胸後の高度の癒着であり, 具体的には 開胸部と肺との癒着および食道切除後の縦隔への肺の高 度の癒着である。ここ数年で急増している胸腔鏡下食道 切除術 (Video-assisted thoracoscopic esophagectomy; VATS-E）の術後においては胸壁と肺との間の癒着が少 なく, 食道癌術後の肺切除術の主な問題点は切除肺と再 建胃管または縦隔との間の癒着である．肺癌手術をも胸 腔鏡下に行うためには, 食道癌術後の肺切除術における 癒着剥離の要点を把握しておく必要がある.

しかし, 食道切除術後の肺癌手術の報告自体が少ない. 今回, 胸腔鏡下食道切除術後の開胸側に発生した原発性 肺癌 2 例に対して胸腔鏡下肺葉切除術を施行したので報 告する。

独立行政法人国立病院機構長崎医療センター呼吸器外科 原稿受付 2015年 9 月14日

原稿採択 2016年 5 月 30 日

本論文の要旨は第 25 回日本内視鏡外科学会総会にて発表し た.

\section{症 例 1}

75 歳男性. 胸部食道癌(扁平上皮癌, Mt, T2N0M0, c-Stage II) に対して, 胸腔鏡下食道切除術, 2 領域リンパ 節郭清，および胸骨後経路の胃管再建を行った．胸部操 作は左下側臥位にて 5 ポート (第 5, 7 肋間で前腋窩線上 と後腋窩線上にそれぞれ $12 \mathrm{~mm}$ ポートを 1 力所，第 3 胁間中腋窩線上に $5 \mathrm{~mm}$ ポートを 1 カ所）を用いて行っ た. 術後補助療法は行わなかった。術後経過観察の胸部 $\mathrm{CT}$ で右上葉 S3 に緩徐な増大傾向を示す $25 \mathrm{~mm}$ 大の孤 立性肺腫瘤影を認めた。気管支鏡検査で扁平上皮癌の診 断であり, 原発性肺癌か, 食道癌肺転移かの診断は不明 であった。初回手術から 9 力月後に肺悪性腫瘍に対する 手術を行った。

手術所見：肺切除は左下側臥位にて腋窩小開胸（第 4 肋間中腋窩線上）および 3 ポートを用いて胸腔鏡補助下 に行った. 前回手術時の胸壁ポート孔と肺との間に癒着 を全く認めなかった(Fig. 1A)，胸骨後経路で再建された 胃管を前縦隔に確認した，右上葉が気管後リンパ節領域 （\#3p）を中心として縦隔上部と強固に癒着し(Fig. 1B), 下葉は気管分岐部リンパ節（\#7）から肺䩗帯の領域にか 

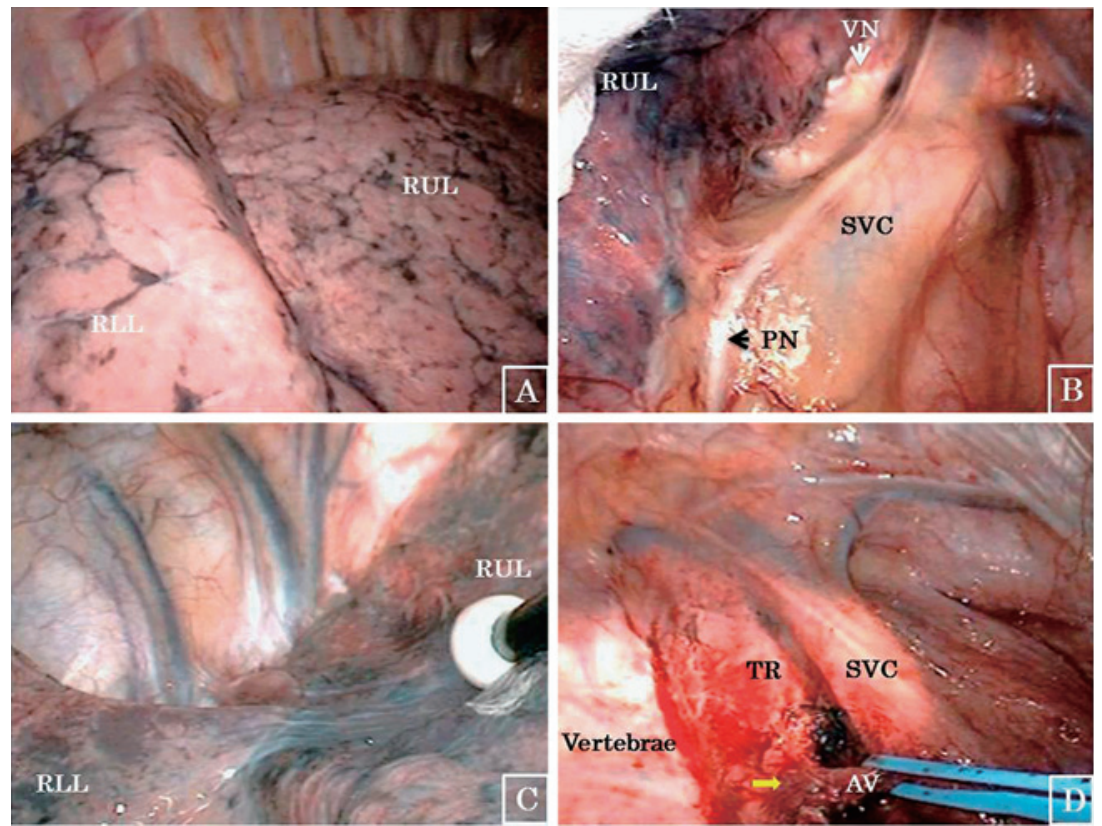

Fig. 1 (A) There was no adhesion between the chest wall and lung. (B) There was tight adhesion between the retro-tracheal space and upper pulmonary lobe. However, the para-tracheal mediastinum pleura and lymph node were intact without adhesion. The vagus nerve could be identified (white arrow). (C) The RUL and RLL became incarcerated in the retrotracheal space and post-cardiac space after esophagectomy. (D) The proximal stump of the azygos vein after esophagectomy was firmly fixed to the right tracheobronchial angles (yellow arrow).

*RUL: right upper lobe; RLL: right lower lobe; VN: vagus nerve; PN: phrenic nerve; TR: trachea; AV: azygos vein.

けて後縦隔と強固に癒着していた (Fig. 1C). 右上葉の強 固な癒着を縦隔から剥離するのに時間を要した。気管傍 リンパ節領域 $(\# 2 R, \# 4 R)$ は正常縦隔胸膜に覆われてお り肺の癒着は認めず，迷走神経の一部を視認できた，癒 着を剥離し上葉を完全に遊離した後に右上葉切除を行っ た。肺動静脈および気管支の処理は問題なかった。また 右気管気管支リンパ節 (\#4R) 腫大を認めたため, 上縦隔 リンパ節郭清を行った. 奇静脈の中枢側切離端は右主気 管支に強固に癒着していた（Fig. 1D）が，右主気管支周 囲リンパ節 (\#10) および\#4R リンパ節の郭清に支障はな かった，食道癌手術時に左反回神経麻痺を合併していた ため, 右上縦隔郭清においては右反回神経を損傷しない ように，\#2R リンパ節はサンプリングに止めた。手術時 間 374 分, 出血 $100 \mathrm{~g}$. 病理組織診断では, 原発性肺癌 （扁平上皮癌, pT1bN0M0, pStage IA）であった。合併 症なく,術後 7 日目に退院した. 術後 4 年 10 力月経過し, 再発所見を認めていない.

\section{症 例 2}

60 歳女性. 胸部食道癌 (扁平上皮癌, Mt, TlbN0M0, c-Stage I) に対して, 胸腔鏡下食道切除術, 2 領域リンパ 節郭清, および後縦隔経路胃管再建を行った。胸部操作 は腹臥位にて 4 ポート (第 5,7 肋間後腋窩線上のそれぞ れに $12 \mathrm{~mm}$ ポートを 1 力所, 第 9 肋間肩甲線上に 12 $\mathrm{mm}$ ポートを 1 力所, 第 3 肋間中腋窩線に $5 \mathrm{~mm}$ ポート を 1 力所）を用いて気胸併用下に行った。 術後補助療法 は行わなかった。術後経過観察の胸部 CT で右上葉 S3 に緩徐な増大傾向を示す孤立性肺腫瘤影を認めた。気管 支鏡検查で腺癌の診断であった. 初回手術から 16 力月後 に右上葉肺癌（S1, T1aN0M0, c-Stage IA）に対する手 術を行った。

手術所見：肺切除は左下側臥位にて 4 ポート（第 4,6 肋間前腋窝線上, 第 7 肋間中腋窩線前, 第 6 肋間肩甲線 前方のそれぞれに $12 \mathrm{~mm}$ ポートを 1 力所）を用いて完全 

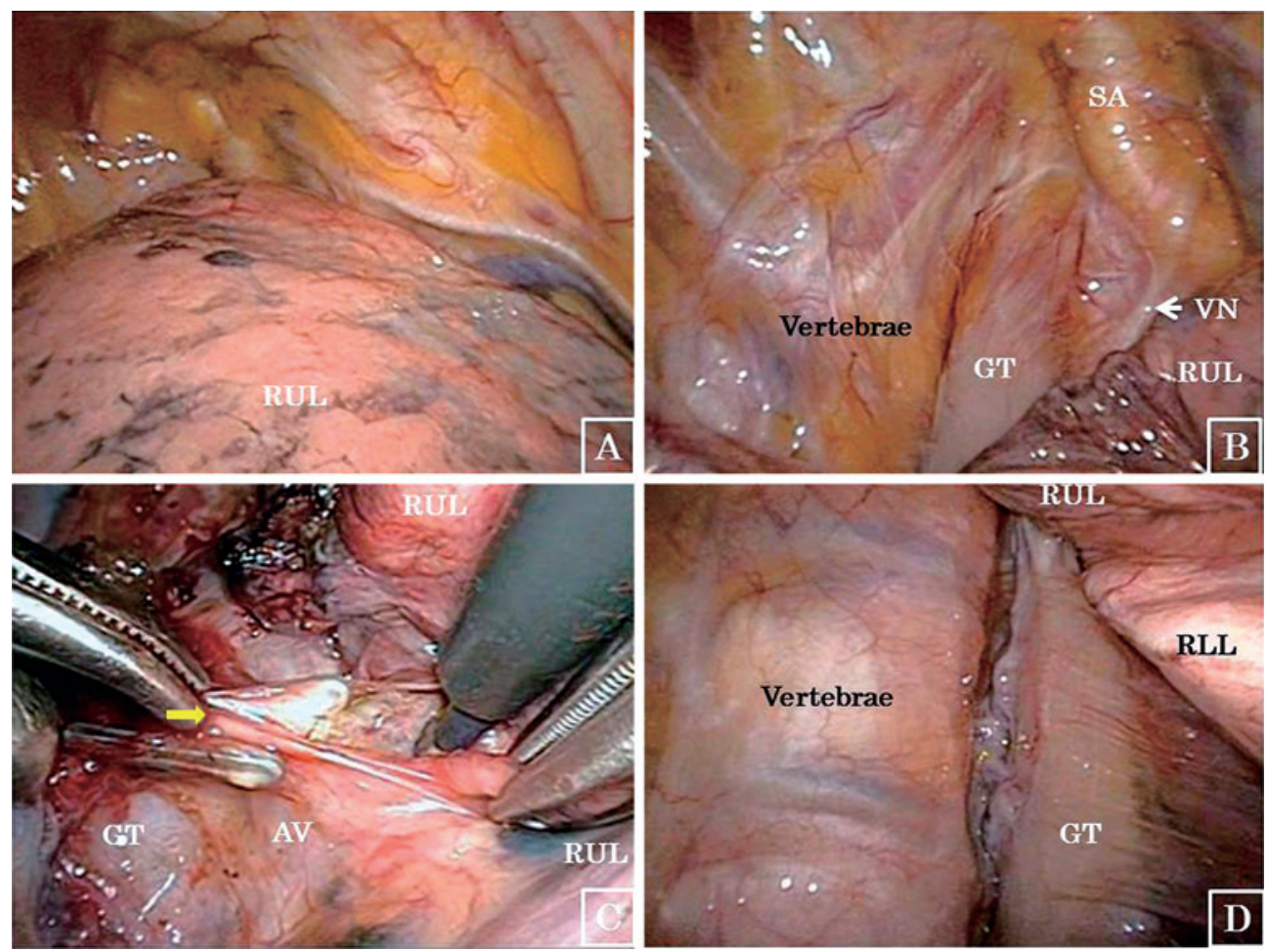

Fig. 2 (A) There was no adhesion between the chest wall and lung. (B) There was loose adhesion between the gastric tube and upper pulmonary lobe due to the serosa of the gastric tube. (C) The clipped distal stump of the azygos vein could be confirmed between the gastric tube and RUL. (D) The subcarinal space was filled with the gastric tube. Subcarinal lymph node dissection could be omitted.

*GT: gastric tube.

胸腔鏡下に行った．前回手術時の胸壁ポート孔と肺との 間に癒着を全く認めなかった (Fig. 2A). 後縦隔には食道 切除後の空間に後縦隔経路で再建された胃管が存在した (Fig. 2B)．再建胃管と肺と奇静脈中枢側断端との間には 器質化した癒着を認めた (Fig. 2C)。胃管と肺との間の剥 離に関しては, 術前に造影 CT にて右胃大網動脈が再建 胃管の背側（椎体側）を走行していることを確認した。 再建胃管を損傷しないように留意し, 胃管漿膜面の血管 を視認しながら剥離操作を進めた。 食道切除術の影響は 上縦隔リンパ節郭清に問題なかった。本症例では食道切 除術時にすでにNo.107 リンパ節郭清が済んでおり, 術前 CT で気管分岐部リンパ節の腫脹を認めず，また気管分 岐部リンパ節領域に再建胃管 (Fig. 2D)が存在したため, 下縦隔郭清を行わなかった. 第 4 肋間前腋窩線上の 12 $\mathrm{mm}$ ポート孔を拡大し切除肺を摘出した。手術時間 240 分, 出血 $15 \mathrm{~g}$. 最終病理診断では Large cell neuroendocrine carcinoma（LCNEC）で, 胸膜浸潤あり, pT2aN0
M0, Stage IB であった. 合併症なく術後 7 日目に退院し た. 術後 24 力月に右下葉に再発し部分切除を行った. そ の後は再発を認めていない.

\section{考察}

周術期管理, 手術手技の進歩, 術前 - 術後の補助化学 療法の開発による食道癌外科治療の成績向上 ${ }^{1.22}$ に伴い, 食道癌術後に二次癌として肺癌を重複した症例や肺転移 再発症例を対象として, 同側開胸後の肺切除を行う機会 が増えてくると予想される. 食道癌症例への他臓器重複 癌は約 $20^{3)} \sim 30 \%{ }^{4)}$ に認められ, そのうち合併頻度が高い のは頭頸部癌 $53.4 \%$, 胃癌 $25.2 \%$ であるが, 肺癌の重複 が $3.1 \%$ に認められる ${ }^{4}$. 一方で, 本邦の食道癌根治切除 後の再発は $28 \sim 47 \%^{2.3 .5)}$ に認められ, 再発の大部分は 2 年以内に生じる ${ }^{2,3)}$. そのうち遠隔蔵器再発は肺・肝・ 骨・脳の順に多く ${ }^{6}$, 血行性再発において最も切除の対象 となっているのが肺転移である2.7). 
食道癌根治術後の経過観察において肺転移は数 $\mathrm{mm}$ 大の小結節で発見されることが多く ${ }^{8}$, 転移性か原発性か の形態診断が困難な場合がある。単発の肺腫瘍では原発 性肺癌の可能性を考え確定診断または経過観察を行う。

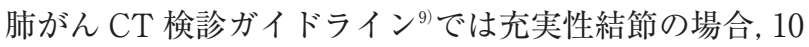
$\mathrm{mm}$ 以上であれば確定診断を行い，5〜10 $\mathrm{mm}$ であれば 経過観察を行い, 増大があれば確定診断をつけることが 推奨されている。一方で, 多発性肺腫瘍を認めた場合は 肺転移再発を考える. 食道癌再発例の予後は極めて不良 であるため ${ }^{6)}$, 可能な限り確定診断を行うことが望まし い. 未確定診例では食道癌原発巣の病理学的進行度, 腫 瘍マーカー, 他藏器転移の有無などを考慮し総合的に判 断する.

根治切除後の再発に対する切除術の有効性について は, 『食道癌診断・治療ガイドライン』(6) では「行うょうに 勧めるだけの根拠が明確でない（推奨グレードC)」であ るが，外科治療によって長期生存または治癒が得られる 症例があることも確かであり ${ }^{2,6)}$, 積極的な治療が望まれ る. 宇田川ら ${ }^{10)}$ は 3 個以上の同時多発例と切除不能例を 除いた肺転移に対して, 鏡視下部分切除および術後化学 療法を行い, 2 年生存率 $70 \%$ という良好な成績を収めて いる. 一方, 成宮ら ${ }^{11)}$ は, 肺転移はまず化学療法で奏功 するかどうかを見極め, 短時間では多発せず 1 ～個で完 全奏功が得られなければ積極的に切除を行い, さらに化 学療法を追加するとしている。 また, 孤立性肺転移に対 する転移巣切除と術後化学療法が予後改善に寄与するこ とも報告されている ${ }^{12}$. ただし, 食道癌術後肺転移は両側 多発性肺転移が多く ${ }^{13)}$, 再発診断時には耐術不能な全身 状態であることも経験されるため, 外科治療が行われる ことは稀であり ${ }^{2,6)}$, 非外科治療を選択せざるを得ない. 非外科治療の選択に一定の方針はないが, 化学療法・放 射線療法・化学放射線療法などを行うよう勧められてい る(推奨度グレード $\mathrm{B})^{6}$.

開胸食道切除後の原発性肺癌手術は困難とされ, 開胸 で行われることが多い. 開胸肺切除となる原因のひとつ は同側開胸部と肺との間の広範で高度な癒着である。一 方で, 開胸ではなく胸腔鏡下に食道切除術が行われた場 合は, 肺と胸壁との間の癒着が軽減される. 食道癌に対 する胸腔鏡下食道切除術はここ数年で増加しており, 日 本胸部外科学会の全国集計によれば 2011 年に行われた 食道切除 5430 例中 1542 例（28\%）が鏡視下手術で行わ れている ${ }^{14)}$. 食道癌をVATS-Eで手術した症例に限れ
ば，胸壁と肺との間の癒着が少なく，肺切除術の主な問 題点は切除予定肺と再建胃管と縦隔との間の癒着とな る.

食道癌術後の肺癌手術においては, 第一に食道切除術 後の縦隔上部および後縦隔への肺の癒着パターンが再建 経路により異なる点を考慮する必要がある (Fig. 3). 食道 切除術では縦隔上部から後縦隔にかけて縦隔胸膜を広く 切開するため, 食道切除後の縦隔では広い範囲で縦隔胸 膜が久損し，そこに右肺上葉および下葉が強固に癒着す る. 自験例 1 のように胸骨後経路再建の場合は, 胃管の 剥離操作は不要であるが, 食道切除後の縦隔と肺との間 に強固な癒着が存在するために，縦隔と肺との間の癒着 剥離は容易ではない. 鏡視下での癒着剥離に難渋すると きはこの時点で直視下または開胸手術へ移行することも 検討すべきである. 一方で, 最も多く施行されている後 縦隔経路再建の場合は, 再建胃管が食道切除後の縦隔上 部〜後縦隔と肺との間に介在し, 緩衝材としての役割を 果たすため, 胸膜を欠損した縦隔面に肺が直接癒着しな い.さらに，肺と接する再建胃管との間には胃管の漿膜 が介在するため, 肺と胃管との間の癒着は軽減される. 胃管の剥離において, 術前に造影 CT にて右胃大網動脈 の走行部位を把握しておき血管損傷による胃管の血流障 害を起こさないこと，またエネルギーデバイスによる胃 管の熱損傷に留意することが肝要である.

つぎに, 食道切除後の右上葉切除術において注意すべ き癒着剥離は, 第一に奇静脈切離端周囲の癒着である. 自験例 2 では肺と胃管との間, および奇静脈中枢側切離 端と肺との間に器質化した膜様癒着が存在し, 切離ライ ンの見極めが大切であった。肺門上極の剥離のために必 要な癒着剥離であるが, 奇静脈切離端を把持する必要も あったため, 大血管損傷のリスクを想定しておくべきで ある。 そこで, 奇静脈が上大静脈へ流入する部位には食 道切除術の影響は及んでいないので, 奇静脈切離端の剥 離に先立ち, 肺門前方の剥離操作を先行し, 上大静脈流 入レベルで奇静脈中枢側を剥離テーピングしておくこと が望ましい. 自験例 1,2 ともに奇静脈中枢側切離端は右 主気管支へ強固に癒着していたが，結果的に 2 例ともに 奇静脈切離端を主気管支から剥離する必要はなかった。 奇静脈切離端の右主気管支への癒着は, 上縦隔リンパ節 郭清および右上葉気管支の処理において支障とならな かった.

最後に, 食道切除時の縦隔リンパ節郭清を考慮すると, 
retrosternal route

with gastric tube reconstruction

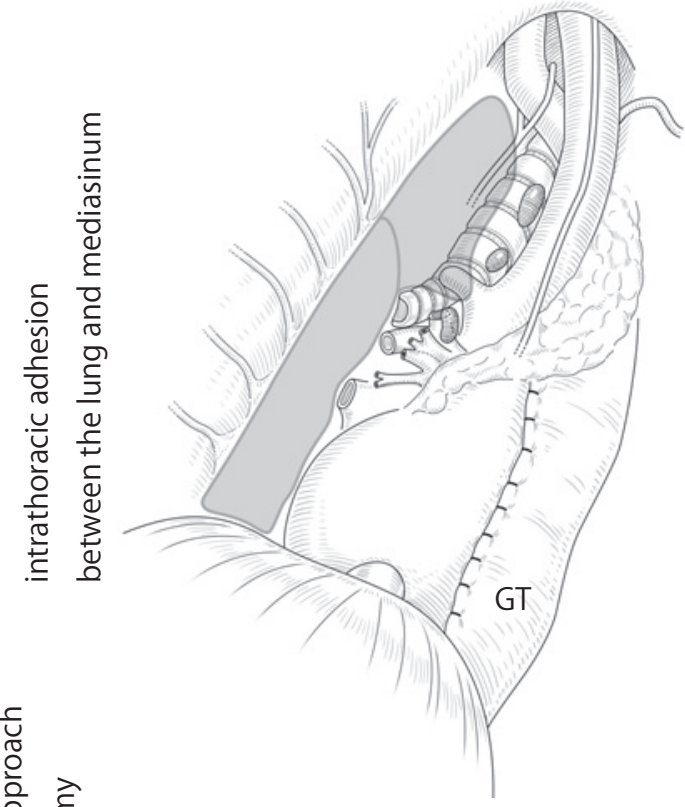

Open thoracotomy post mediastinal route

with gastric tube reconstruction

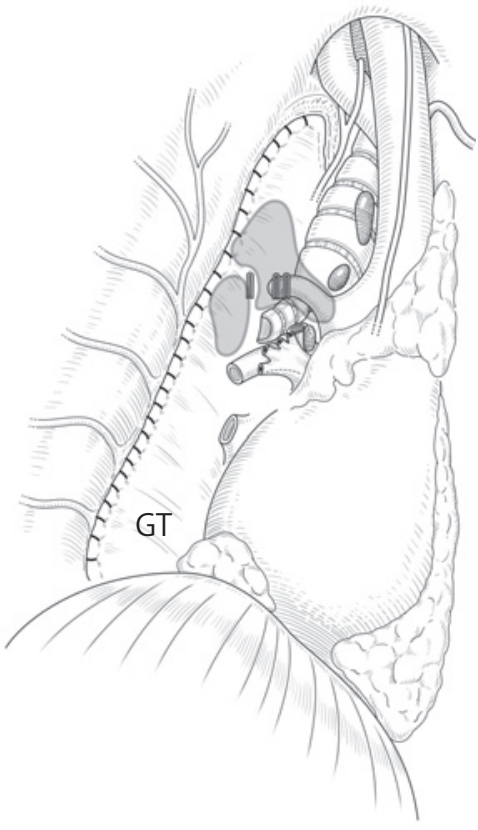

Complete VATS
右肺癌手術時に追加する必要がある縦隔の郭清領域は, 右迷走神経より前方の上縦隔リンパ節領域のみ（\#2の一 部と＃）となる点である. 胸部食道癌では反回神経周囲 の頸部上縦隔リンパ節郭清は重要であり, 食道切除術に はNo.106recR は必ず郭清される。同様に気管分岐部リ ンパ節 (No.107) および主気管支下リンパ節 (No.109) も, 胸部食道癌の 2 群リンパ節に属しており, 食道切除術に は必ず郭清される。食道癌における No.106recR は肺癌 における\#2R の一部に相当し, No.107 に No.109を加え た領域は肺癌における\#7 相当する. そのため, 食道切 除後の肺癌手術時には上縦隔リンパ節のうちの反回神経 周囲領域, および下縦隔リンパ節領域には郭清する組織 がないはずである。一方で, 右迷走神経より前方の領域 は食道癌における気管前リンパ節 (No.106pre) に相当し, 上部胸部食道癌において 3 群リンパ節郭清を行う場合以 外には食道切除時に郭清がなされることはなく, 肺切除
時に郭清する必要がある領域である. 以上より, 食道切 除後の右肺切除において術前画像でリンパ節腫大が指摘 されなかった場合は, 反回神経麻瘏や再建胃管の損傷の リスク回避を念頭に, 反回神経周囲および下縦隔のリン パ節郭清は行わなくて良いと考える. 敢えて郭清を行う 場合は反回神経や再建胃管の損傷に十分に留意しなけれ ばならない。

以上より, 食道癌手術がVATS-Eで行われた症例で は，胸壁と肺の癒着を認めない，もしくは軽度な場合が ある.さらに再建が後縦隔経路で行われた場合は肺と縦 隔の癒着も軽度であり, 奇静脈切離端および胃管の剥離 の要点を踏まえれば, 食道癌術後の原発性肺癌手術を完 全胸腔鏡下肺切除で行うことができる可能性がある。た だし，胸骨後経路再建の場合は，肺と縦隔との癒着剥離 が容易ではないため, 胸腔鏡補助下手術または開胸手術 が検討されてよいと考える。 


\section{利益相反}

本論文について申告する利益相反はない.

\section{文献}

1. 宮田博志, 山崎 誠, 黒川幸典, 瀧口修司, 中島清一, 藤 原義之, 他. 最新の診療ガイドラインの実地診療応用への 手引き：食道癌診断・治療ガイドライン。外科治療 2011; 104: 429-38.

2. 藤也寸志, 坂口善久, 池田 貯, 大垣吉平, 沖 英次, 南 一仁, 他. 進行食道癌の治療; エビデンスレベルと治療成 績の向上を目指して : 根治切除後のフォローアップ法と 再発の治療. 消外 2008; 31: 1653-62.

3. 桑野博行, 福地 稔, 加藤広行. 消化器癌の術後フォロー アップとサーベイランス：食道癌. 消外 2009; 32: 101727.

4. 幕内博康. 食道癌の治療法の変遷と治療成績. 日気食会報 2010; 61: 57-62.

5. Toh Y, Oki E, Minami K, Okamura T. Follow-up and recurrence after a curative esophagectomy for patients with esophageal cancer: the first indicators for recurrence and their prognostic values. Esophagus 2010; 7: 3743.

6. 再発食道癌の治療. 日本食道学会編. 食道癌診断・治療ガ イドライン 2012 年 4 月版. 東京 : 金原出版 ; 2012: 82-5.

7. 藤也寸志. フォローアップと再発の治療, 悪性腫瘍. 桑野 博行編. エキスパートが伝える食道外科 up-to-date. 東
京：中外医学社；2010: 299-309.

8. 堤 謙二, 宇田川晴司, 木八下義宏, 上野正紀, 峯 真司, 江原一尚. 食道癌 6. 転移診断. 臨消内科 2008; 23: 9981004.

9. 肺がん CT 検診ガイドライン. 低線量 CT による肺がん 検診の肺結節の判定基準と経過観察の考え方 第 3 版 [Internet]. 日本 CT 検診学会肺がん診断基準部会編. 東 京：日 本 CT 検診学会; c2010-2013 [updated 2013 May ; cited 2016 May 1]. Available from : http://www. jscts.org/pdf/guideline/gls3rd130521.pdf.

10. 宇田川晴司, 堤 謙二, 木ノ下義宏, 上野正紀, 峯 真司, 江原一尚, 他. 原発巣から見た対応 診断と治療 食道癌 の遠隔転移. 外科 $2005 ; 67: 890-3$.

11. 成宮孝祐, 井手博子, 中村 努, 太田正穂. 転移癌に対す る薬物療法 術後再発食道癌の集学的治療. 日本臨床 2003; 61: 495-501.

12. Chen F, Sato K, Sakai H, Miyahara R, Bando T, Okubo K, et al. Pulmonary resection for metastasis from esophageal carcinoma. Interact Cardiovasc Thorac Surg 2008; 7: 809-12.

13. 守尾 篤, 宮元秀昭, 泉 浩, 山崎明男, 穴見洋一, 細 田泰之, 他. 食道癌術後肺転移の 1 切除例. 日胸 2000; 59: 293-7.

14. Amano J, Kuwano H, Yokomise H. Thoracic and cardiovascular surgery in Japan during 2011. Annual report by the Japanese Association for Thoracic Surgery. Gen Thorac Cardiovasc Surg 2013; 61: 578-607. 


\title{
VATS lobectomy for primary lung cancer after VATS-E for esophageal cancer: Report of two cases
}

\author{
Ryoichiro Doi, Ryusuke Machino, Shigeyuki Morino \\ Hiroharu Tsuji, Tsutomu Tagawa
}

Department of General Thoracic Surgery, Nagasaki Medical Center

Pulmonary resection of lung cancer after surgery for esophageal cancer is difficult because of severe adhesion between the lung, thorax, and mediastinum. We acquired knowledge about thoracoscopic adhesiolysis involving two cases of pulmonary resection for lung cancer after video-assisted thoracoscopic esophagectomy (VATS-E) for esophageal cancer. Case 1: A 75-year-old man underwent VATS-E with lymph node dissection and gastric tract reconstruction via a posterior mediastinum route. Nine months after VATS-E, he was treated for lung cancer with right upper lobectomy and upper mediastinum dissection. Case 2: A 60-year-old woman underwent VATS-E with lymph node dissection and gastric tract reconstruction via a poststernum route. Sixteen months after the esophagectomy, she was treated for lung cancer with right upper lobectomy and upper mediastinum dissection. Characteristically, there was no adhesion between the chest wall and lung after VATS-E. Adhesion between the lung and mediastinum was different depending on the routes of gastric tract reconstruction. The tightest adhesion existed at the right bronchus and proximal stump of the azygos vein resected in the esophagectomy, but there was no problem regarding dissection of \#4 and \#10 lymph nodes. Dissection of \#2 and \#7 lymph nodes could be omitted, as this had been completed during VATS-E.

(C) The Japanese Association for Chest Surgery (JACS) 